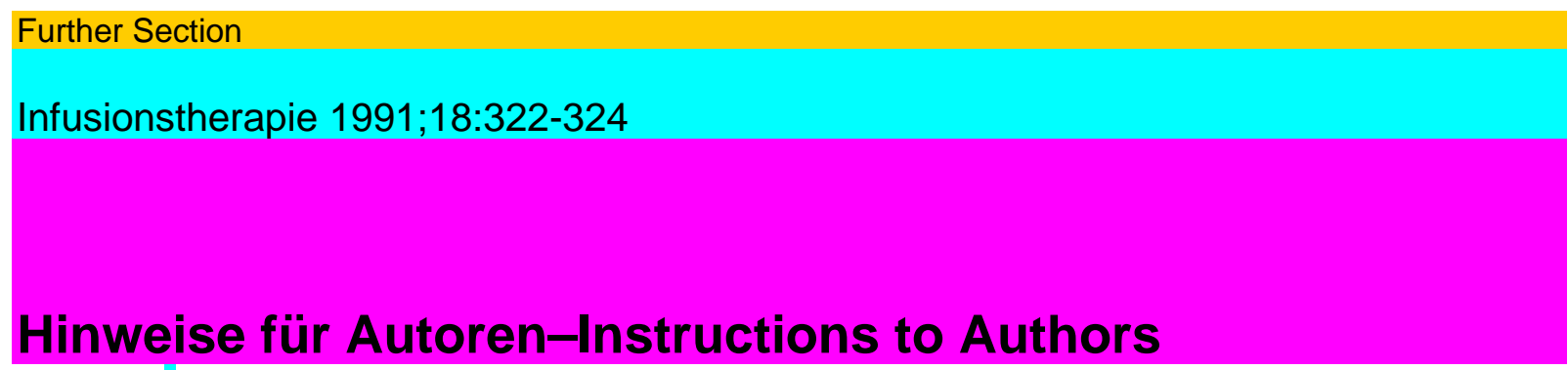

1. Allgemeines, Verlagsrecht

Bitte senden Sie Ihr Manuskript direkt an den Verlag S. Karger, z.Hd. Frau Anne Schieber, Postfach 1724, D-8034 Germering/ München.

Beiträge erscheinen als Übersichtsarbeiten, Originalarbeiten, lau-fende klinische Studien, Kurzmitteilungen, Kasuistiken, klinisch-pathologische Konferenz, Kongreßberichte, Informationen für die Klinik und Briefe an die Herausgeber.

Originalarbeiten, laufende klinische Studien und Kurzmitteilungen sollten in englischer Sprache abgefaßt werden. Alle anderen Beiträge können wahlweise in deutscher oder englischer Sprache ein-gereicht werden.

Das Manuskript soil in satzreifem Zustand in dreifacher Ausferti-gung eingereicht werden. Die Entscheidung über die Aufnahme erfolgt aufgrund mehrerer Gutachten. Eine Kopie des Manuskripts soil grundsätzlich beim Autor verbleiben.

Typographische Gestaltung und redaktionelle Bearbeitung sind dem Verlag vorbehalten.

Die Arbeit darf nicht gleichzeitig bei einer anderen Publikation eingereicht sein. Es ist Sache des Autors, die Nachdruckerlaubnis für Abbildungen, Tabellen usw. aus anderen Publikationen zu beschaffen. Mit der Annahme des Manuskriptes zur Publikation gehen alle Rechte auf den Verlag über. Ohne schriftliche Genehmi-gung des Verlages dürfen diese Publikationen oder Teile daraus nicht in andere Sprachen übersetzt oder in irgendeiner Form mit mechanischen oder elektronischen Mitteln (einschließlich Fotoko-pie, Tonaufnahme und Mikrokopie) reproduziert oder auf einem Datenträger oder einem Computersystem gespeichert werden. Geschützte Markennamen müssen mit einem hochgestellten ${ }^{\circledR}$ be-zeichnet werden. Die Verantwortung für die korrekte Befolgung dieser Vorschrift liegt ausschließlich beim Autor.

2. Manuskripte Diese sollen in l'A-zeiligem Abstand geschrieben sein, links und rechts einen angemessenen breiten Rand aufweisen und (einschließlich Titelseite und Literaturverzeichnis) kontinuierlich durchnumeriert sein. Folgende Gliederung wird empfohlen:

Titelseite mit Titel und Kurztitel der Arbeit in Deutsch und Eng-lisch; Autorenangabe; Institutsangabe in der Landessprache der Autoren.

Zusammenfassung und Schlüsselwörter in Deutsch und Englisch. Zusammenfassungen sollen 20 Schreibmaschinenzeilen nicht über-schreiten. In die Zusammenfassung gehören keine Literaturzitate, Tabellen, Abbildungen und Abbildungs- und Tabellenhinweise so-wie allgemein gehaltene Aussagen. Zu einer Arbeit gehören 3-5 Schlüsselwörter.

Textseiten der Arbeit mit Gliederung in Einleitung, Material und Methoden (oder: Patientengut und Methoden), Ergebnisse, Dis-

kussionen. Fußnoten (gegebenenfalls numeriert) am unteren Rand jeder Textseite. Abkürzungen bitte möglichst sparsam verwenden. Bei speziellen Abkürzungen jeweils beim ersten Auftreten das Wort ausschreiben und die später verwendete Abkürzung in Klammern folgen lassen: z.B. Adenosin-Monophosphat (AMP). 
Danksaguiigen sollten unmittelbar dem Text folgen und dem Literaturverzeichnis vorangestellt sein.

Das Literaturverzeichnis soil nur die im Text zitierten Publikationen enthalten. Die Literatur ist entsprechend der Reihenfolge im Text zu numerieren. Es sollen nur Arbeiten, die entweder publi-ziert oder zur Publikation angenommen sind, zitiert werden. Der Passus «in Vorbereitung» oder «persönliche Mitteilung» ist zu ver-meiden.

1. General Remarks - Publishing Laws

Please send your manuscript directly to S. KARGER Publishers attn.: Mrs. Anne Schieber, P.O. Box 1724, D-8034 Germering/ Munich (FRG).

Contributions are classified as review articles, original papers, ongoing clinical studies, short communications, casuistic contributions, clinical pathological conference, congress reports, clinical information and letters to the publisher.

Original papers, ongoing clinical studies and short communications should be written in English. All other contributions may be handed in optionally in German or English.

The manuscript should be submitted in triplicate, ready for printing. Acceptance of a manuscript is based on the evaluation by several referees. The author should always keep a copy of the manuscript. The publisher reserves the right to edit the manuscript and decide on the layout. The manuscript is received with the understanding that it is not under simultaneous consideration for publication elsewhere. It is the authors responsibility to obtain permission to reproduce illustrations, tables etc. from other publishers. Once the manuscript is accepted for publication, all the rights will be retained by the publisher. The publication, or parts of it, may not be translated into other languages, or reproduced by any mechanical or electronic means (including photocopying, recording and microcopying), or stored in a retrieval system without the publisher's written permission.

Registered trade names must be marked with the superscript registration symbol ${ }^{\circledR}$. It is the sole responsibility of the author to ensure that this rule is followed properly.

2. Manuscripts

The manuscripts should be typed in a spacing of IV2 lines with adequately wide margins (left and right). They should be consecutively numbered (including front page and reference list). We recommend the following division:

Front page with title and short title in German and English; author's name, institute name in the native language of the authors.

Summary and key words in German and English. Summaries should not exceed 20 typewritten lines. Summaries should not include any references, tables, figures, references to figures and tables and general statements. Each article should have 3-5 key words.

Text pages should be divided into introduction, materials and methods (optionally patients and methods), results, discussion.

Footnotes (with numbers) are placed at the bottom of each page of the text.

Please use abbreviations as economically as possible. Special abbreviations should be written in full when first mentioned followed by the abbreviation in parenthesis, e.g. adenosinemonophosphate (AMP). Acknowledgements should be placed directly after the text, and before the list of references.

The list of references should include only the publications cited in the text. The references should be numbered according to their order of appearance in the text. It is recommended to quote only articles which have been either published already or accepted for publication. 
Please avoid passages like 'in preparation' or 'personal communication'. Quotes from references are inserted into the text with or without the name of the first author, e.g. [1], or Romberg [1] or Romberg et al. [1]. For references the following examples are compulsory:

Ernahrung und Tumorerkrankungen

Ein Standardwerk über Prophylaxe und Therapie von Tumorleiden durch Erné

Herausgeber: Schauder P. (Göttingen) Auflage 1991, VIII + 702 Seiten, 63 Abbildungen und 105Tabellen, gebunden, DM 145,-ISBN 3-8055-5383-8

Die Möglichkeiten, durch ernährungsmedi-zinische Maßnahmen zur Linderung desTumorproblems beizutragen, werden derzeit ungenügend genutzt. Das vorliegende Buch propagiert, basierend auf dem gegen-wärtigen Wissen über die Wechselwirkun-gen zwischen Ernahrung und Tumorleiden, ein Umdenken.

Beziehungen zwischen Ernahrung und Tumorleiden reichen von der Tumorinduktion über die Tumorprävention, die Tumorthera-pie bis hin zur Beseitigung verschiedener Formen tumorassoziierter Mangelemäh-rung. Der unterschiedliche Wissensstand in den einzelnen Bereichen wird einer kriti-schen Analyse unterzogen. Bei aller Beto-nung bestehender Wissenslücken bleiben die Beiträge konstruktiv. Der am Problem vorwiegend klinisch interessierte Leser fin-det eiße Fülle praktischer Hinweise für den sinnvollen Einsatz ernährungsmedizinischer Strategien im Rahmen seiner klini-schen Tätigkeit. Dem vorwiegend wissen-schaftlich interessierten Leser werden zahl-reiche Anregungen für seine weiteren wis-senschaftlichen Arbeiten geboten. Der Kreis behandelter Themen reicht von der Diskussion ethischer Probleme, etwa über den Sinn ernährungsmedizinischer Maßnahmen in Grenzsituationen, bis zur Darstellung neuer wissenschaftlicher Konzepte und Forschungsansätze, wie des Konzepts der Immunonutrition Oder des Einsatzes stabiler Isotope zu Forschungszwecken.

Ärzte, Epidemiologen, Ernährungswissen-schaftler aber auch Laien werden das Buch nützlich finden und, so die Erwartung der Autoren, zur Überzeugung gelangen, daß

emährungsmedizinische Maßnahmen er-heblich zur Linderung des Tumorproblems beitragen können.

$1 / 8^{7 / 8} / 8 . ; \% 1 / 8^{1 / 83} / 8^{5} / 8^{\wedge \wedge}$

KARGEH

Verlag für Medizi $\pi$ und Naturwissenschaften $\mathrm{GmbH}$ - Angerhofstraße $9 \cdot$ Postfach 1

- D-8034 Germering - Telefon 0 89/84 3035 - Telefax 0 89/8 418083 - Telex 524865 324

Hinweise fur Autoren $\mathbf{~ I n s t r u c t i o n s ~ t o ~ A u t h o r s ~}$

Literaturzilate werden mit oder ohne Angabe des Erstautors in den Text eingefügt, z. B. [1] oder Romberg [1] oder Romberget al. [1 ].

Zur Abfassung von Literaturzitaten gelten folgende Beispiele:

Darstellangsschema einer Zeitschriftenreferenz: Kauffman HF, van der Heide S, Beaumont F, Blok H, de Vries K: Class-specific antibody determination against Aspergillus fumigatus by means of the enzyme-linked immunosorbent assay. III. Comparative study: IgG, IgA, IgM ELISA titers, percipitating antibodies and IgE binding after fractionation of the antigen. Int Arch Allergy Appl Immunol 1986;80:300-306.

Darstellangsschema einer Buchreferenz: 
Hardy WD Jr, Essex M: FeLV-induced feline acquired immune deficiency syndrome: A model for human AIDS, in Klein E (ed): Acquired Immunodeficiency Syndrome. Prog Allergy. Basel, Kar-ger, 1986, vol 37, pp 353-376.

Die Zahl von Abbildungen und Tabellen soil niedrig gehalten werden und darauf abzielen, den Text zu erläutern. Abbildungen werden mit (Abb. 1), Tabellen mit (Tab. 1) in den Text eingefügt. Bereits im Text genannte Zahlen bedürfen keiner Wiederholung in einer Tabelle. Umgekehrt brauchen die in Tabellen zusammenge-stellten Zahlen nicht im Text wiederholt zu werden. Farbabbildun-gen können angenommen werden, bedürfen aber eines Reproduk-tionsund Druckkostenzuschusses, den der Autor zu tragen hat. Abbildungsvorlagen sind 3 fach als Papierabzüge einzureichen. Vor-lagen nicht aufkleben, lochen oder mit Büroklammern anhcften; auf der Rückseite den Namen des Autors, den Titel des Beitrags. die Angabe, wo «oben» ist, sowie die Bildnummer angeben. Alle Abbildungen und Tabellen sind mit einer Legende zu versehen. Alle Legenden einer Arbeit werden auf einer gesonderten Seite zusammengestellt. Die Legenden sind kurz und präzise zu halten und sollen die Abbildungen bzw. Tabellen vollständig erklä-ren. Die Interpretation der Daten erfolgt nicht in der Legende, sondern ausschließlich im Text.

Autorenadresse

Postanschrift des Autors am Schluß der Arbeit vollständig angeben.

3. Umfang von Manuskripten

Originalarbeiten (Gliederung s.o.) sollen 10 Textseiten nicht über-schreiten.

Kurzmitteilungen folgen der Gliederung von Originalarbeiten und sollen 5 Textseiten, 5-10

Literaturhinweise und max. 1 Abbildung und 1 Tabelle (oder wahlweise 2 Abbildungen oder Tabellen) nicht überschreiten. Schwerpunkte von Kurzmitteilungen sollen neue Ergebnisse wissenschaftlicher Arbeiten, auch in Form sogenanntcr vorläufiger Mitteilungen, und auch neue Studienansätze - experi-mentell oder klinisch - sein. Verlag und Schriftleitung wollen erreichen, daß solche Arbeiten innerhalb kürzester Zeit publiziert werden. Selbstverständlich bleibt es dem Autor überlassen, zu einem späteren Zeitpunkt eine ausführliche Fassung einzureichen.

Übersichtsarbeiten folgen nicht der Gliederung von Originalarbeiten. Titelseite, Zusammenfassung und Literaturverzeichnis (s.o.) sind jedoch erforderlich.

4. Kosten und Sonderdrucke

Übersteigen die Kosten der Autorkorrektur 10\% der Satz-kosten, müssen diese dem Autor in Rechnung gestellt werden. Dem Autor stehen 40 Gratissonderdrucke seiner Arbeit zu.

Outline of a magazine reference:

Kauffman HF, van der Heide S, Beaumont F, Blok H, de Vries K: Class-specific antibody determination against Aspergillus fumigatus by means of the enzyme-linked immunosorbent assay . III. Comparative study: IgG, IgA, IgM ELISA titers, precipitating antibodies and IgE binding after fractionation of the antigen. Int Arch Allergy Appl Immunol 1986;80:300-306. Outline of a book reference:

Hardy WD Jr, Essex M: FeLV-induced feline acquired immune deficiency syndrome: A model for human AIDS, in Klein E (cd): Acquired Immunodeficiency Syndrome. Prog Allergy, Basel, Kar-ger, 1986, vol 37, pp 353-376.

The number of figures and tables should be limited and aim to illustrate the text. Figures are listed in the text as [fig. 1], tables as [table 1]. Figures already mentioned in the text need not be repeated in a table. Accordingly, numbers used in tables need not be repeated in the text. Figures in color may be accepted, provided the author is prepared to defray the costs involved. Do not fasten original figures with glue or paper clips or punch holes in them. Please state on the back 
the author's name, the title of the article, the 'top' instruction and the number of the figure. All figures and tables must include a legend. All legends should be listed together on a separate page. Legends should be kept short and precise and should illustrate the figures and tables exhaustively. The data should not be interpreted in the legend but exclusively in the text. Author's address

Please give the author's full address at the bottom of the article.

3. Volume of Manuscripts

Original papers (framework see above) should not exceed 10 text pages.

Short communications adhere to the framework of original papers and should not exceed 5 text pages, 5-10 references and a maximum of 1 figure and 1 table (optionally either 2 figures or tables). Short communications should focus on the result of scientific studies, also in the form of so called provisional reports as well as new scientific approaches either experimental or clinical. It is the publisher's and the editorial staffs aim to manage the publishing of such articles within the shortest period of time possible. It goes without saying that the author is at liberty to hand in a complete version at a later date.

Review articles do not adhere to the framework of original papers, the title page, a summary and a list of references (see above) are, however, compulsory.

\section{Costs of Reprints}

The author will be charged for corrections to the galley proofs entailing expenses in excess of $10 \%$ of the original typesetting costs. The author is entitled to 40 free reprints of his or her article. 